\title{
The Real Exchange Rate and Economic Growth: Some Observations on the Possible Channels ${ }^{1}$
}

\author{
Martín Rapetti ${ }^{2}$
}

\begin{abstract}
A recent body of empirical research has documented a strong association between the level and volatility of the RER and economic growth. This research has relied on a variety of econometric techniques applied to large cross-country data sets. Although the documented positive effects of both RER competitiveness and stability on growth appear to be robust, it is still unclear what the mechanisms driving these associations are. Several explanations have been proposed, but their theoretical examination and empirical validation is still in an infant stage. I analyze the mechanisms that have been proposed and evaluate them in light of the documented empirical evidence. My reading is that two of them adjust to the empirical findings best: the financial globalization channel and the tradable-led growth channel. I conclude that since these mechanisms are not mutually exclusive, both might have some explanatory power.
\end{abstract}

JEL: O24, F43, F31, O11.

Keywords: real exchange rate, growth, development, growth econometrics.

\footnotetext{
${ }^{1}$ Paper prepared for a volume in honor of Roberto Frenkel. I thank Jaime Ros, Ricardo FfrenchDavis and Emiliano Libman for helpful comments.

2 Associate Researcher at CEDES, at IIEP-University of Buenos Aires, and Assistant Researcher at CONICET. Email to: m.g.rapetti@gmail.com.
} 


\section{Introduction}

The idea that a stable and competitive real exchange rate (RER) is favorable for economic development now has a respectable status in policy and academic circles. ${ }^{3} \mathrm{~A}$ recent body of empirical research documenting a strong association between the level and volatility of the RER and economic growth has contributed a great deal to consolidate this view. Research has mostly relied on a variety of econometric techniques applied to large cross-country data sets. Although the documented positive effects of both RER competitiveness and stability on growth appear to be robust empirical findings, it is still unclear what the mechanisms driving these associations are. Several explanations have been proposed, but their theoretical examination and empirical validation is still in an infant stage.

The purpose of this chapter is to explore the merits and weaknesses of the proposed channels in light of recent empirical research. In section 2, I summarize the main empirical findings coming out of the econometric literature analyzing the RER-growth association. In section 3, I discussed the mechanisms that might explain this association. In section 4, I discuss how the proposed mechanisms relate to the empirical findings reviewed in section 2 . I close the paper with some remarks and suggesting avenues for future research.

It is no mystery how the theme of this chapter relates to Roberto Frenkel's work. Roberto has been among the pioneering and leading voices arguing that developing countries should aim at maintaining a stable and competitive RER for development purposes. His work on this subject has been extensive, insightful and influential.

\section{The RER in growth regressions}

Recent empirical literature analyzing the association between RER levels and economic growth has been mostly carried out through growth regressions. ${ }^{4}$ Finding a measure of the level of the RER to be placed on the right-hand side of a growth regression is not straightforward. To be meaningful, it needs to be comparable across countries (i.e., cross-section analysis) or across time (i.e., time series analysis) or both (i.e., panel data analysis). To address these complications, the standard strategy has been to construct "RER misalignment" indexes, which are used as right-hand variables in the regressions.

Since a misalignment index is the ratio of actual to "equilibrium" RERs, a critical step in this methodology is the definition and estimation of the latter. There are two standard notions of equilibrium RER in the literature. ${ }^{5}$ One is linked to Balassa's (1964) and Samuleson's (1964) observation that in small open economies purchasing power parity (PPP) somewhat holds for tradable prices and that non-tradable prices tend to be lower

\footnotetext{
${ }^{3}$ I follow the definition of nominal exchange rate as the domestic price of a foreign currency. Consequently, a higher RER implies a more competitive or depreciated domestic currency in real terms.

${ }^{4}$ Other strategies - like case and episode studies or historical narratives - have also been used. For studies of growth episodes, see Hausmann et. al. (2005), and Freund and Pierola (2012). For historical analyses of specific cases in Latin America, see Frenkel and Rapetti (2008 and 2012).

${ }^{5}$ For a critical assessment of the notion of exchange rate equilibrium, see Taylor (2004).
} 
in less developed countries because real wages in those countries are also lower. According to the Balassa-Samuelson hypothesis, equilibrium RERs in developed countries tend to be lower than in developing countries. As a hypothesis for long-run behavior of RERs, it has supporting evidence (Taylor and Taylor, 2004).

A second approach follows the popular view pioneered by Meade (1951) and suggests that the equilibrium level of the RER is one consistent with the simultaneous attainment of internal and external balance. The most troublesome aspect of this approach relates to the appropriate definition of "external balance". In many cases, this is pragmatically defined as a situation in which the current account is financed by "sustainable" net capital inflows (Hinkle and Montiel, 1999), which is also a vague concept. According to this view, the equilibrium RER is determined by long-run economic fundamentals affecting external sustainability, including the net foreign asset position, terms of trade, productivity, the degree of trade openness and government consumption.

In line with these theoretical views, two empirical approaches have been followed to construct misalignment indexes. One of them defines the equilibrium RER as the purchasing power parity level adjusted by the Balassa-Samuelson effect (PPP-based). PPP-based equilibrium RERs are estimated through equations like (1), in which the level of the RER $(q)$ is regressed by some measure of the degree of economic development, usually the GDP per capita $(Y)$.

$\operatorname{lnq}=\alpha_{1}+\beta_{1} \ln Y+\epsilon$

The other empirical strategy relies on either single equation or general equilibrium macroeconometric models, in which the estimated equilibrium RER depends on economic fundamentals (fundamentals-based). In a single-equation framework, its empirical estimation is similar to equation (1), but the number of regressors is extended to include a measure of degree of trade openness, the net foreign asset position, the terms of trade, and the ratio of government consumption over GDP. A fundamentsbased estimation is represented by equation (2), which coincides with equation (1), except for the vectors $\mathrm{X}$ and $\mathrm{v}$ that include the additional regressors and their corresponding parameters.

$\ln \mathrm{q}=\alpha_{2}+\beta_{2} \ln \mathrm{Y}+\mathrm{vX}+\varepsilon$

In cross-section estimations, the variables and the error terms in equations (1) and (2) appear with a subscript $i$ indicating the country. In panel data environments, an additional subscript $t$ is included to indicate period. Panel data estimations also include period fixed-effects.

The misalignment index is then constructed as the ratio of actual to equilibrium RER $\left(m=q / q^{*}\right)$; the latter $\left(\mathrm{q}^{*}\right)$ being estimated either through equation (1) or (2). When the exchange rate is defined as the domestic price of a foreign currency - as in this papervalues of the misalignment index higher (lower) than one imply that the RER is undervalued (overvalued). Defined this way, the misalignment index can also be called RER undervaluation index, and with the inverse definition of the exchanger rate, RER overvaluation index. ${ }^{6}$

\footnotetext{
${ }^{6}$ This would be defining the nominal exchange rate as the units of foreign currency exchanged for one unit of domestic currency.
} 
The growth regression literature has found substantial evidence that higher RER levels tend to be associated with higher GDP per capita growth rates. This association appears robust to changes in the estimation technique - cross-section OLS, panel data (fixed and random effects), dynamic panel data (GMM), non-linear panels and panel cointegration techniques - , the number of control variables and the data sources for both the dependent and independent variables (Penn World Tables, International Financial Statistics, World Development Indicators, Madisson Historical Statistics). This literature has also shown that RER volatility - typically measured as the standard deviation or coefficient of variation of the RER - is negatively associated with GDP growth.

A comprehensive survey of this literature is beyond the scope of this chapter. There are a number of issues, however, that are worth discussing in some detail because they are important for the subsequent analysis in sections 3 and 4 . These regard whether the observed positive association between RER levels and economic growth varies a) across countries and periods, $b$ ) between cases of RER overvaluation and RER undervaluation and c) between indexes of misalignment used. I briefly discuss these issues below.

\subsection{Countries and periods}

Many studies analyze the RER-growth association in samples exclusively comprised of developing countries - e.g., Cottani et al. (1990), Dollar (1992) and Gala (2008) while others in samples also including a relatively small number of developed countries -i.e., Razin and Collins (1999) and Aguirre and Calderon (2008). Rodrik (2008) explicitly tests whether the association only occurs in developing countries. He uses a PPP-based index of RER undervaluation in a fixed-effects model for a panel of up to 184 countries between 1960 and 2004. He defines developing countries as those with a GDP per capita less than $\$ 6,000$ and finds that the positive relationship between RER undervaluation and economic growth is stronger and more significant for developing than developed countries. Rapetti et al. (2012) replicate Rodrik's work and show that if the threshold is instead selected from anywhere in the $\$ 9,000-\$ 15,000$ range, the estimated effect of RER undervaluation on growth is also large and highly significant for developed countries. To address the issue in more detail, they develop a series of alternative classification criteria and empirical strategies to evaluate the existence of asymmetries between groups of countries. They find that the effect of currency undervaluation on growth is indeed larger and more robust for developing economies.

Many studies use sample periods starting after 1980. This might raise the issue of whether the documented association is exclusive of the so-called second financial globalization era. Rodrik (2008) estimates the effect of undervaluation on growth in developing countries for two distinct periods (1950-79 and 1980-2004) and finds that it is significant in both with virtually identical magnitudes. Using several alternative definitions of developing countries, Rapetti et al. (2012) get similar results to Rodrik's, also when dividing the sample in an alternative split for the pre- and post-globalization eras: 1950-74 and 1975-2004. Extending the analysis for a substantially longer period, Di Nino et al. (2011) also find supporting evidence that the relationship is strong for developing countries and weak for advanced countries in both the pre-and post-World War II period (1861-1939 vs. 1950-2009). 


\subsection{Asymmetries}

The first studies analyzing the relationship between RER misalignments and economic growth were motivated by the idea that RER overvaluation hinders growth. For instance, Cottani et al. (1990) use a fundamentals-based index of RER overvaluation in a cross-section regression for 24 developing countries over1960-83 and find a statistically significant negative relationship between the variables. Dollar (1992) also finds a robust negative relationship between a PPP-based RER overvaluation index and economic growth in a cross-section study for 95 developing countries over 1976-85. A common reading of these results was that RER misalignment - not just overvaluationhurts economic growth.

More recently, researchers began to investigate more carefully whether the effects of RER overvaluation and undervaluation are asymmetric. Razin and Collins (1999) construct a fundamentals-based index of RER overvaluation and use it for a pooled sample of 93 developed and developing countries over 16 to 18 year periods since 1975 . They find that overvaluation hurts and undervaluation favors growth. The effect of overvaluation appears stronger though. Aguirre and Calderón (2005) find that the estimated coefficients of their misalignment indexes are larger for cases of overvaluation than those of undervaluation; but here again the positive effect of undervaluation on growth is significant both statistically and economically. Rodrik (2008) finds that overvaluation hurts growth and undervaluation favors growth and no significant difference in terms of the size of each effect. Rapetti et al. (2012) find similar results to Rodrik's, although the effect of overvaluation is slightly higher in absolute terms than that of undervaluation. Bereau et al. (2012) use panel non-linear techniques - i.e., a Panel Smooth Transition Regression model - to capture whether there are asymmetries between RER undervaluation and overvaluation. They find robust evidence that undervaluation accelerates and overvaluation decelerates growth.

\subsection{Misalignment indexes}

An important conclusion that emerges from the empirical literature is that the positive association between RER levels and growth does not appear to depend on the way the misalignment index is constructed. Aguirre and Calderón (2005) develop three fundamentals-based indexes of RER overvaluation using panel cointegration and time series techniques for a panel of 60 developed and developing countries over 1965-2003. They find that GDP per capita growth correlates negatively with the three of them. The authors obtain very similar results when the fundamentals-based indexes are replaced by a PPP-based index.

MacDonald and Vieira (2010) estimate seven equilibrium RERs using fixed-effects and random-effects models for a panel of 90 countries between 1980 and 2004. They use different combinations of regressors (GDP per capita, net foreign assets, terms of trade and government consumption) in their estimations. Then, they construct a PPP-based undervaluation index similar to Rodrik's and six fundamentals-based undervaluation indexes. In all cases, they find a significant and positive correlation with economic growth, which is stronger for developing and emerging countries. The estimated effect of RER undervaluation on growth is very similar with the seven indexes.

The results in Aguirre and Calderon (2005) and MacDonald and Vieira (2010) suggest that in practice the estimation of PPP-based and fundamental-based equilibrium RERs 
are very similar. Berg and Miao (2010) address this issue explicitly. They use Penn World Tables 6.3 data to estimate a fixed-effect model for a PPP-based undervaluation index like (1) and for fundamentals-based undervaluation index like (2) using as additional regressors the terms of trade, the degree of openness and government consumption and investment (both as a share of GDP). They find that the two indexes are virtually indistinguishable from each other; the correlation coefficient between them is 0.96 .

Summing up, the evidence gathered from the growth regression literature suggests the following. First, the effect of RER misalignment on growth comes in the form of undervaluation stimulating and overvaluation hurting growth. The negative effect of latter is likely to be stronger in absolute terms than that of the former. Second, these effects are especially attributable to the experience of developing countries. Third, there is no evidence that the documented effects correspond to a specific historical period. Fourth, although they have different theoretical background and implications, PPPbased and fundamentals-based misalignment indexes appear to be empirically indistinguishable from each other.

\section{Possible mechanisms behind the positive RER-growth association}

Recent research has been much more successful at establishing a robust positive association between RER levels and economic growth than at uncovering the mechanisms behind it. Although there might be some room for debate, there seems to be a wide acceptance that the causality behind the documented correlation runs from RER levels to economic growth. Every-day experience shows that governments use a variety of instruments -including exchange rate, monetary, fiscal, incomes and capital management policies - to manage the level and evolution of the RER with real objectives. Thus, the relevant question is not about causality but about the mechanism explaining why undervalued (overvalued) RER levels would favor (hurt) economic growth. Several possible mechanisms have been proposed in the literature. I briefly discuss four of them. ${ }^{7}$

The first one is what Berg and Miao (2010) call the "Washington Consensus" view, which states that a RER misalignment implies some sort of macroeconomic disequilibrium that is itself bad for growth. Presumably anchored in Walrasian general equilibrium theory, this view suggests that a misaligned RER is a disequilibrium relative price that induces inefficient allocation of resources lowering economic growth. Although it has been inspired by cases of RER overvaluation, this view considers that RER undervaluation also has deleterious effects on growth. The evidence gathered in econometric studies of the RER-growth association goes against the Washington Consensus view. As reviewed in section 2, this literature has robustly found that while RER overvaluation tends to hinder, RER undervaluation stimulates growth (Berg and Miao, 2010).

Another proposed mechanism suggests that higher RER levels tend to increase the saving rate that, in turn, translates into faster capital accumulation and growth. The main weakness of the "saving channel" is theoretical: it is unclear how higher levels of

\footnotetext{
${ }^{7}$ A slightly different classification of the mechanisms is presented in Skott et al. (2012)
} 
the RER would affect growth via changes in the saving rate. Using an inter-temporal optimization framework, Montiel and Serven (2009) cannot identify a mechanism through which changes in the RER level affect the saving rate. Their baseline model shows that a rise in the equilibrium value of the RER leads to a permanent increase in income and consumption, leaving the saving rate unchanged. ${ }^{8}$

Razmi et al. (2012) develop a structuralist framework to show that higher RER levels help accelerate capital accumulation and economic growth in a small open economy. In their baseline model, the saving rate depends on functional income distribution. A rise in the RER allows for higher rate of capital accumulation but has an ambiguous effect on the wage share and aggregate saving rate.

Levy-Yeyati and Sturzengger (2009) also relate the RER and the saving rate to distributional changes. A transition to a higher RER typically reduces real wages and transfers income from workers to firms. Following the seminal contribution by DiazAlejandro (1963), if workers have a propensity to spend greater than firms, this redistribution increases the saving rate. It is not clear, however, that the redistribution must raise accumulation. As the original analysis of Díaz-Alejandro shows, a RER devaluation leading to higher saving can be contractionary. This issue has been examined extensively in Kaleckian models (e.g. Bhaduri and Marglin 1990, and Blecker, 1989), in which it is shown that both expansionary and contractionary cases are possible.

Besides the above-mentioned theoretical difficulties, there is an additional one. It is not clear in these accounts why higher saving and investment rates require not merely higher but undervalued (i.e., above equilibrium) RER levels as found in the empirical literature.

I call the third proposed mechanism the "financial globalization channel" because it focuses on how foreign capital movements to developing countries affect economic performance through transitory RER misalignments. The extreme form of this mechanism arises when RER overvaluation caused by capital inflows leads to currency and financial crises with long-lasting negative impacts on growth. A number of developing countries - mostly in Latin America - have experienced this type of boomand-bust episodes. ${ }^{9}$ Many of them began with the implementation of macroeconomic stabilization programs that combined fixed or semi-fixed exchange rates, liberalized current and capital accounts, and the deregulation of domestic financial markets. In a first phase, the combination of these elements stimulated capital inflows that appreciated the RER, expanded economic activity and induced current account deficits. In many cases, a consumption boom ensued without a rise in the investment rate. Even when investment did increase, the appreciation of the RER favored investment in nontradable activities with little increase in the export capacity that was required to repay foreign debt.

\footnotetext{
${ }^{8}$ It is questionable whether an inter-temporal equilibrium framework is useful to analyze the RER-growth link, because the econometric evidence points to an association between disequilibrium RER levels and economic growth.

9 The work of Roberto Frenkel (1983) was pioneer analyzing and formalizing this kind of dynamics. See also Frenkel and Rapetti (2009).
} 
In a second phase, the excessive external borrowing raised concerns about the sustainability of the fixed exchange rate regimes and triggered speculative attacks against the domestic currencies. The effect of capital outflows was typically contractionary. The domestic banking systems - which were short in foreign currency and long in local assets - faced liquidity problems and in many cases went bankrupt, exacerbating the negative impact on economic activity. In cases in which the collapse of the financial system was severe and the external debt burden very high, the crises had long-lasting effects on economic growth. Clear examples of these dynamics are the stabilization programs based on active crawling pegs (the so-called tablitas) in Argentina, Chile and Uruguay during the late 1970s, which ended up in severe debt crises that crippled growth during the 'lost decade' of the 1980s. Other stabilization programs leading to crises occurred during the 1990s in Mexico (1994-95), Brazil (1998-99), Argentina (2001-02) and Uruguay (2002). Taylor (1998) suggests that this kind of cyclical dynamics was also observed in the South East Asian crises of 1997-98, and Bagnai (2012) argues similarly for the current crisis in the southern European countries.

Historical record is supportive of this mechanism for the case of RER overvaluation and low or negative growth; it is more controversial whether it can also account for the observed positive association between undervalued RERs and higher growth. Several authors have indicated that undervalued RERs help stabilize long-term growth by limiting external debt accumulation and avoiding contractionary effects of sudden stops (Prasad et al, 2007). Undervalued RERs typically generate current account surpluses and facilitate foreign exchange reserve accumulation. Current account surpluses and large stocks of foreign exchange reserves in turn operate as an insurance against international financial instability and sudden stops. Recent research seems to support this view. Aizenman and Lee (2007) find evidence suggesting that international reserve accumulation in emerging markets has been carried out as a self-insurance strategy to protect the economy from sudden stops. Polterovich and Popov (2002) and Levi Yeyati and Sturzenegger (2007) find a positive correlation between foreign reserve accumulation and RER levels, and also between reserve accumulation and economic growth. Similarly, Prasad et al (2007) find that current account balances are highly and positively associated with both undervalued RERs and economic growth.

The financial globalization channel is somewhat related to the saving channel. The former states that international capital markets operate with many imperfections that negatively affect long-term economic performance, particularly in developing countries. Consequently, these countries need to establish safe linkages with international markets in order to minimize their reliance on foreign savings. A higher RER helps reduce domestic absorption of tradables while promotes domestic production of tradables, thus lowering foreign saving.

Notice, however, the important differences between both channels. The saving channel primarily focuses on the level of savings and assumes that higher saving rates translates into higher capital accumulation and growth. As mentioned above, it has not been adequately established in theoretical terms the necessary link between saving rates, investment and RER levels. The financial globalization channel focuses on the composition of savings, highlighting the imperfections of international capital markets and their potential negative effects on growth. 
The fourth mechanism can be referred to as the "tradable-led growth" channel. Essentially, this mechanism sees economic development as a process characterized by a rapid and intense structural transformation from low-productivity to high-productivity activities that are largely tradable. "Modern" tradables have traditionally been associated with manufactures but there is now recognition that some services (e.g., software) and knowledge-intensive agricultural activities (e.g., seed production) are also part of this group. The tradable-led growth channel can be seen as consisting on three broad elements:

1) Modern tradable activities are intrinsically more productive or operate under some sort of increasing returns to scale.

2) Given this trait, the reallocation of (current and future) resources to these activities - i.e. structural change - accelerates GDP per capita growth.

3) Accumulation in these activities depends on their profitability, which in turn depends on the level of the RER. Rapid capital accumulation requires a sufficiently competitive (undervalued) RER to compensate for the market failures caused by the increasing returns.

A large number of specific mechanisms have been advanced with this general logic. For instance, Rodrik (2008) indicates that modern tradable activities are affected disproportionally by market and institutional failures. Using an endogenous growth model, he shows that the resulting misallocation of resources towards non-tradables leads to slower economic growth; an undervalued RER can be a second-best policy that compensates for the market and institutional failures, improves tradable profitability, and accelerates economic growth.

Rodrik is, of course, not the first to emphasize the important interplay between RER levels and market failures in economic development. Learning externalities, for instance, imply that infant industries can benefit from temporary protection against foreign competition via a transitory RER undervaluation (Ros, 2001). Similarly, temporary RER overvaluation can lead to de-industrialization and lower growth - as in the Dutch disease case - when tradable firms' production is subject to some form of increasing returns to scale (e.g., Krugman, 1987, and Ros and Skott, 1998). The opposite case - transitory RER undervaluation - can spur a virtuous dynamics of structural change and economic development (Rapetti, 2013). Models of export-led growth have emphasized positive externalities that are not equally prevalent in nonexport activities; policies reallocating resources to export industries therefore promote higher growth in these models (e.g. de Melo, 1992).

Another popular mechanism emphasizes that the lack of foreign exchange may constrain economic growth in developing countries. This idea has a long tradition in structuralist economics and CEPAL (Ocampo, 2012) and in the balance-of-paymentsconstrained growth literature initiated by Thirwall (1979). In some accounts within these traditions, it has been emphasized that higher (lower) RER levels tend to relax (exacerbate) the balance of payments constraint and thus accelerate (decelerate) growth. ${ }^{10}$ Although it is based on a somewhat different rationale, this mechanism can be

\footnotetext{
${ }^{10}$ Porcile and Lima (2010) and Razmi et al (2012) are recent examples.
} 
considered part of a broadly defined tradable-led growth channel. Both channels share the view that economic development concurs with the expansion of tradable activities and that higher RERs favor their profitability and consequently capital accumulation and economic growth. ${ }^{11}$

\section{An evaluation of the proposed channels in light of the empirical evidence}

The prediction of the Washington Consensus view that undervalued RERs affect economic growth negatively collides with empirical evidence, which shows exactly the opposite. No persuasive mechanism, on the other hand, has been proposed within the saving channel. Thus, in this section, I consider the other two proposed mechanisms: the financial globalization channel and the tradable-led growth channel. I evaluate them in light of the empirical findings discussed in section 2 .

The financial globalization channel poses that the failures in the international capital markets affect developing countries in the form of excessive volatility, sudden stops and external crises. Thus, lowering the reliance on foreign savings can enhance economic growth in these countries. Since it lowers the demand of foreign saving, this view predicts that a higher RER level should accelerate growth in developing countries.

Fundamentals-based misalignment indexes are adequate to assess this mechanism empirically. The equilibrium level of the RER estimated for these indexes is the one that allows the economy achieve internal and external balances simultaneously. Its level is determined by a sustainable (or equilibrium) flow of foreign saving. Since developing countries need to demand less-than-equilibrium foreign finance to protect themselves from international capital markets failures, the financial globalization channel would predict that undervalued (overvalued) RERs enhance (hurt) economic growth in developing countries. The empirical evidence reviewed in section 2 supports this prediction. It is important to notice, however, that econometric evidence suggests that the documented positive association between RER levels and growth holds for developing countries not only in the second globalization period (i.e., since circa mid 1970s), but also before it. Thus, the financial globalization channel explains at best only part of observed association and another explanation of it is needed.

I now turn to the question of how to evaluate empirically the tradable-led-growth channel. Recall it consists of three related elements. Modern tradable activities are special because they operate under some sort of increasing returns to scale. As a result, a relative expansion of these activities compared to others accelerates GDP per capita growth. Their expansion, in turn, depends on the level of the RER because it determines the profit rate of tradables. For simplicity, the latter can be stated formally as the rate of capital accumulation in the tradable activities $\left(g_{T}\right)$ being a positive function of their profit rate $\left(r_{T}\right)$ relative to the profit rate in the foreign country $\left(r_{T}^{*}\right)$.

\footnotetext{
${ }^{11}$ It could even be argued that tradable production also operates under some broad form of increasing returns in the external-constrained growth story. The expansion of tradable activities generates a positive externality by raising the net supply of foreign exchange and thus providing the rest of the economic sectors foreign exchange at relatively lower cost. Given that exporters do not internalize the positive external effect of supplying additional unit of foreign exchange, an undervalued RER is required.
} 
$g_{T}=g\left(r_{T} / r_{T}^{*}\right) \quad$ with $g^{\prime}>0$

The parity between profit rates in the home and foreign country $\left(r_{T}=r_{T}^{*}\right)$ implies

$\frac{P_{T}-Y_{T}-W L_{T}}{P_{T} K_{T}}=\frac{P_{T}^{*}-Y_{T}^{*}-W L_{T}^{*}}{P_{T}^{*} K_{T}^{*}}$

Were $P_{T}$ is the price of tradable goods, $Y_{T}$ is tradable goods output, $W$ is the nominal wage rate, $K_{T}$ is the capital stock in the tradable goods sector and the asterisk (*) refers to the foreign country. Assuming that technology for tradable production is similar in both countries - meaning that the output-capital ratios are the same-, that the law of one price holds and that labor is homogenous across sectors within countries, the parity condition (4) implies the intuitive result that relative wages expressed in common currency need to be proportional to the ratio of tradable labor productivities.

$q_{w} \equiv \frac{E W^{*}}{W}=\frac{Y_{T}^{*} / L_{T}^{*}}{Y_{T} / L_{T}} \equiv \frac{1}{y_{T}}$

Where $E$ is the nominal exchange rate, $q_{W}$ is the foreign to domestic wage ratio expressed in common currency and $y_{T}$ the relative labor productivity in tradables. The RER is defined as the relative price between baskets of goods and services produced or consumed in different countries expressed in the same currency.

$q \equiv \frac{E P^{*}}{P}$

where $P^{*}$ and $P$ are foreign and domestic price indexes. Both price indexes in expression (6) are composed by tradable and non-tradable prices. Assuming that the law of one price holds for tradables, and that the weighting scheme of $P$ and $P^{*}$ are similar, we get

$$
q=\left(\frac{E P_{T}^{*}}{P_{T}}\right)^{1-\theta}\left(\frac{E P_{N}^{*}}{P_{N}}\right)^{\theta}=\left(\frac{E P_{N}^{*}}{P_{N}}\right)^{\theta}
$$

where $P_{N}$ is the price of non-tradables, $\theta$ is the share of non-tradables in both price indexes and $1-\theta$ that of tradables. Non-tradable prices are largely determined by the nominal wage rate, typically in some sort of imperfect competition environment. Thus, further assuming that non-tradable prices are determined by a mark-up $(\mu)$ over average costs, expression (7) turns into

$$
q=\left(\frac{\left(1+\mu^{*}\right) E W^{*}}{(1+\mu) W} \frac{Y_{N}^{*} / L_{N}^{*}}{Y_{N} / L_{N}}\right)^{\theta}=\left(\delta q_{W} y_{N}\right)^{\theta}
$$

Where $\delta$ is the foreign to domestic mark-up factor ratio, and $y_{N}$ is the relative labor productivity in non-tradables. Given that $\delta$ and $y_{N}$ are relatively stable in the short and medium run, expression (8) reveals the intuitive result that the behavior of RER is largely determined by the evolution of relative wages $\left(q_{W}\right)$ in such time horizons.

Plugging (5) into (8), we obtain the level of RER that is compatible with the parity 
between the tradable profit rates in the home and the foreign country, which is referred to as $\bar{q}$

$\bar{q}=\left(\delta \frac{y_{T}}{y_{N}}\right)^{\theta}$

The Balassa-Samuelson effect rests on the observation that rich countries have far greater relative labor productivity in tradable than in non-tradable activities compared to poorer countries. The Balassa-Samuelson effect thus predicts that the value of $y_{T} / y_{N}$ in expression (9) and consequently the level of $\bar{q}$ would tend to decrease with the level of the GDP per capita of the home country. This means that the PPP-based equilibrium RERs of the empirical literature discussed in section 2 -i.e., equation $(1)$ - is coincident with the estimation of $\bar{q}$ under the assumption that $\delta$ is constant. ${ }^{12}$ Consequently, a PPP-based misalignment index can be interpreted as an index of the degree of deviation of the tradable profit rate in the home country relative to the foreign country. This is an adequate index to evaluate empirically the tradable-led growth channel.

When the actual level of the RER equals $\bar{q}$-i.e., when the PPP-based misalignment index is equal to one - the profit rate of tradables in the home country is the same as in the foreign country (i.e., the US in the empirical literature). Would modern tradable activities in developing countries grow at catching-up rates with such RER level? There are at least two reasons to expect a negative answer. First, the derivation of $\bar{q}$ only considered relative labor productivities of home and foreign tradable firms. There are a number of elements outside firms making total tradable productivity in developing countries lower than in developed countries. Lack of adequate communication and transportation infrastructure, worse public services and lower aggregate productivity of the economy operate as additional drawbacks for tradable productivity in developing countries that need to be compensated for. Second, even adjusting for these elements it is likely that profit rates in developing countries need to pay a (risk) premium over those paid in developed countries. Consequently, there are good reasons to expect that only an undervalued RER level -i.e., actual RER higher than $\bar{q}$ - would offer proper incentives to expand modern tradable activities in developing countries. In other words, tradable-led growth mechanism would predict that RER undervaluation (overvaluation), measured through a PPP- based misalignment index, would accelerate (decelerate) economic growth in developing countries. As reviewed in section 2, the empirical evidence gathered in the growth regression literature strongly supports this prediction.

\section{Concluding remarks}

During the last decade, a large number of studies have analyzed the relationship between RER levels and economic growth. At this moment, the empirical evidence emerging from this research effort strongly suggests that while RER undervaluation favors economic growth, RER overvaluation hurts it. These effects are observed in developing countries and in the pre- and post- financial globalization periods. These

\footnotetext{
${ }^{12}$ Applying natural logs to expression (9) and substituting $y_{T} / y_{N}$ by GDP per capita $(Y)$ yields equation (1), with $\alpha_{1}=\alpha \ln \delta$ and $\beta_{1}=\theta$.
} 
findings have passed a large number robustness checks, including changes in the econometric techniques and data sets used. Thus, the positive effect of RER levels on economic growth in developing countries can be regarded as a strong empirical observation. The debatable issue remains the mechanism/s involved.

In this chapter, I analyzed the mechanisms that have been proposed in the literature. My take is that two of them adjust to the empirical findings best: the financial globalization channel and the tradable-led growth channel. A drawback of the former is that it predicts that undervalued (overvalued) RERs favor (hurt) growth in developing countries only in the post-globalization period (since the 1970s). Evidence, on the contrary, shows that the association is also observed in the pre-globalization period. The tradable-led growth channel does not make distinction of periods, thus better fitting the evidence. This does not mean that the financial globalization channel holds no water. Since the mechanisms are not mutually exclusive, both might have some explanatory power.

Beside the difference in terms of time periods, it is not possible to discriminate which explanation is more adequate. In a growth econometric set up, the two channels have to be evaluated with different misalignment indexes; the financial globalization channel with a fundamentals-based index and the tradable-led growth channel with a PPP-based index. Since the estimations of equilibrium RERs in both cases end up being indistinguishable from each other, it is not possible to discriminate between the two channels from a growth regression. Because most research on the RER-growth association has been conducted through growth econometric analysis, other strategies need to be explored in the future. In this regards, much could be learnt from the detailed study of specific episodes of growth acceleration triggered by stable and competitive RER strategies. 


\section{References}

Aguirre, Alvaro and Cesar Calderon (2005) "Real exchange rate misalignments and economic performance," Central Bank of Chile, Working Paper No. 315.

Aizenman and Lee (2007) "International Reserves: Precautionary Versus Mercantilist Views, Theory and Evidence" Open Economies Review, 18 (2), pp. 191-214.

Bagnai, Alberto (2012) "Unhappy Families Are All Alike: Minskyan Cycles, Kaldorian Growth, and the Eurozone Peripheral Crises", Documento Técnico, Iniciativa para la Transparencia Financiera, www.itf.org.ar/pdf/documentos/87_2012.pdf.

Balassa, B. (1964): "The Purchasing Power Parity Doctrine: A Reappraisal", Journal of Political Economy, Vol. 72, No. 6, pps. 584-596.

Bereau, S., A. López Villavicencio, and V. Mignon (2012) "Currency Misalignment and Growth: A New Look Using Nonlinear Panel Data Methods", Applied Economics, 44, pp. 3503-3511.

Berg, A y Miao, Y. (2010): "The Real Exchange Rate and Growth Revisited: The Washington Consensus Strikes Back?" IMF Working Paper, No. 10 / 58, Mar.

Bhaduri, Amit and Stephen Marglin (1990) "Unemployment and the Real Wage: The Economic Basis for Contesting Political Ideologies," Cambridge Journal of Economics, Vol. 14, No. 4, pp. 375-393.

Blecker, Robert (1989) "International Competition, Income Distribution and Economic Growth," Cambridge Journal of Economics, Vol. 13, No. 3, pp. 395-412.

Cottani, Joaquin, Domingo Cavallo, and Shahbaz M. Khan (1990) "Real Exchange Rate Behavior and Economic Performance in LDCs," Economic Development and Cultural Change, pp. 61-76.

de Melo, Jaime and Sherman Robinson (1992) "Productivity and Externalities: Mod-els of Export-led Growth," The Journal of International Trade and Economic Development, Vol. 1, No. 1, pp. 41-68.

Diaz-Alejandro, Carlos F.D. (1963) "A Note on the Impact of Devaluation and the Redistributive Effect," Journal of Political Economy, Vol. 71, No. 6, pp. 577580.

Di Nino, V., Eichengreen, B., \& Sbracia, M. (2011). Real Exchange Rates, Trade, and Growth: Italy 1861-2011 (No. 10). Bank of Italy, Economic Research and International Relations Area.

Dollar, David (1992) "Outward-oriented Developing Economies Really do Grow More Rapidly: Evidence from 95 LDCs, 1976-1985," Economic Development and Cultural Change, Vol. 40, No. 3, pp. 523-544.

Frenkel, R. (1983) "Mercado financiero, expectativas cambiarias y movimientos de capital", El Trimestre Económico, 200, pp. 2041-2076.

Frenkel, Roberto and Martin Rapetti (2008) "Five Years of Stable and Competitive Real Exchange Rate in Argentina, International Review of Applied Economics, 22 (2), pp. 215-226.

Frenkel, Roberto and Martin Rapetti (2009) "A Developing Country View of the Current Global Crisis: What Should Not Be Forgotten and What Should Be Done," Cambridge Journal of Economics, Vol. 33, No. 4, pp. 685-702.

Frenkel, Roberto and Martin Rapetti (2012) "Exchange Rate Regimes in the Major Latin America Countries since the 1950s: Lessons from History", Revista de Historia Económica-Journal of Iberian and Latin American Economic History, 30 (1), pp. 157-188.

Freund, Caroline, and Martha Denisse Pierola (2012): "Export surges." Journal of Development Economics 97 (2), pp. 387-395. 
Gala, Paulo (2008) "Real exchange rate levels and economic development: theoretical analysis and econometric evidence," Cambridge Journal of Economics, Vol. 32, No. 2, pp. 273-288.

Hausmann, Ricardo, Lant Pritchett, and Dani Rodrik (2005) "Growth accelerations", Journal of Economic Growth, 10 (4), pp. 303-329.

Hinkle and Montiel (1999): Exchange Rate Misalignment, Oxford University Press.

Krugman, Paul (1987): "The Narrow Moving Band, the Dutch Disease, and the Competitive Consequences of Mrs. Thatcher", Journal of Development Economics, 27 (1-2), pp. 41-55.

Levy-Yeyati, Eduardo and Federico Sturzenegger (2009) "Fear of Appreciation: Exchange Rate Policy as a Development Strategy," in Gil Hammond, Ravi Kanbur, and Eswar Prasad eds. Monetary Policy Frameworks for Emerging Markets: Ed- ward Elgar Publishing, pp. 69-94.

MacDonald, R., \& Vieira, F. (2010). A panel data investigation of real exchange rate misalignment and growth, (No. 3061), CESifo working paper Fiscal Policy, Macroeconomics and Growth.

Meade, James (1951): “The Theory of International Economic Policy: The Balance of Payments", Oxford University Press.

Montiel, Peter and Luis Serven (2009) "Real Exchange Rates, Saving, and Growth: Is There a Link?," Working Paper No. 46, Commission on Growth and Development.

Ocampo, J. A. (2012) "Balance of Payments Dominance: Its Implications for Macroeconomic Policy", paper for the Conference in Honor of Roberto Frenkel.

Porcile, Gabriel and Gilberto T. Lima (2010) "Real Exchange Rate and Elasticity of Labour Supply in a Balance-of-Payments-Constrained Macrodynamics," Cambridge Journal of Economics, Vol. 34, No. 6, pp. 1019-1039.

Prasad, Eswar S., Raghuram G. Rajan, and Arvind Subramanian (2007) "Foreign Capital and Economic Growth," Brookings Papers on Economic Activity, Vol. 1, pp. 153-209.

Rapetti, Martin, (2013) "Macroeconomic policy coordination in a competitive real exchange rate strategy for development", Journal of Globalization and Development, 3 (2), pp. 1-31.

Rapetti, Martin, Peter Skott, and Arslan Razmi (2012) "The Real Exchange Rate and Economic Growth: Are Developing Countries Special?," International Review of Applied Economics, 26 (6), pp. 735-753.

Razin, Ofair and Susan M. Collins (1999) "Real exchange rate misalignments and growth,"in Assaf Razin and Efraim Sadka eds. The Economics of Globalization: Policy Perspectives from Public Economics: Cambridge University Press.

Razmi, Arslan, Martin Rapetti, and Peter Skott (2012) "The Real Exchange Rate and Economic Development," Structural Change and Economic Dynamics, 23 (2), pp. 151-169

Rodrik, Dani (2008) "The real exchange rate and economic growth," Brookings Papers on Economic Activity, Vol. 2, pp. 365-412.

Ros, Jaime (2001) Development Theory and the Economics of Growth: University of Michigan Press.

Ros, Jaime and Peter Skott (1998) "Dynamic effects of trade liberalization and currency overvaluation under conditions of increasing returns," The Manchester School, 66 (4), pp. 466-489. 
Samuelson, P. (1964): “Theoretical Notes on Trade Problems", Review of Economics and Statistics, Vol. 46, No. 2, pps. 145-154.

Skott, P., M. Rapetti, and A. Razmi (2012) "Real exchange rates and the long - run effects of aggregate demand in economies with underemployment, Working Paper 2012-06, University of Massachusetts, Amherst, MA.

Taylor, A. y Taylor, M. (2004): "The Purchasing Power Parity Debate", Journal of Economic Perspectives, 18 (4), pp. 135-158.

Taylor, Lance (1998) "Capital Market Crises: Liberalisation, Fixed Exchange Rates and Market-Driven Destabilisation," Cambridge Journal of Economics, 22 (6), pp. 663-676.

Taylor, Lance (2004) "Exchange rate indeterminacy in portfolio balance, MundellFleming and uncovered interest rate parity models", Cambridge Journal of Economics, 28 (2), pp. 205-227.

Thirwall, A. (1979) "The Balance of Payments Constraint as an Explanation of International Growth Rate Differences", Banca Nazionale del Lavoro Quarterly Review, 32 (128), pp. 45-53. 